\title{
高齢中国帰国者の環境移行と住環境の実態に関する研究
}

\author{
中国残留邦人一世・二世とその配偶者を対象とした調査を通して

\section{RESEARCH ON ENVIRONMENTAL TRANSITION AND LIVING ENVIRONMENT OF ELDERLY JAPANESE PEOPLE FROM CHINA}

Through a survey of first and second generation of Japanese orphans in China and their spouses

\author{
丁 文否*1, 松原茂 樹*2, 下田元毅*3, 木多道宏*4 \\ Wenlei DING, Shigeki MATSUBARA, Motoki SHIMODA \\ and Michihiro KITA
}

\begin{abstract}
This paper studied the environmental transition and living environment of the elderly Japanese people from China. It indicated that: (1) Most of them moved several times after coming to Japan, and the relocations brought them environment changes. (2) Most of them lived in public houses without barrier-free facilities and their home lifestyle can be divided into 3 types. Most of them have passive community lifestyle in neighborhood, and what they value most is the relationship with neighbors. (3) Most of them have weak social connection degree and live very isolated life and cannot adapt to Japanese society well.
\end{abstract}

Keywords: Elderly Japanese People from China, Environmental transition, Housing environment, Neighborhood environment, Social connection, Aging-in-place 高齢中国帰国者, 環境移行, 住宅環境, 近隣環境, 社会的つながり, エイジング・イン・プレイス

\section{1. 研究背景}

第二次世界大戦後、中国特に中国東北部（満州）に多くの日本人 が戦後の混乱によって帰国できず、中国に長期間残留を余儀なくさ れた。1945 年 8 月 9 日時点で、満 13 歳以上の男性・女性たちを 「中国残留婦人等」、13 歳未満で孤児となり中国の養父母に育てら れた人々を「中国残留孤児」と呼び、それらをまとめて「中国残留 邦人」(一世) と総称している注1)。また、中国残留邦人 (一世) から 1945 年 8 月 10 日以降に生まれた子どもを二世と呼んでいる。1972 年、日中国交が正常化して、日本政府は中国残留邦人の帰国問題に 取り組み始め、1975 年から中国残留邦人は徐々に日本に帰国し始め た 1)。帰国した中国残留邦人の中には中国で家族を作った人もおり、 その家族を含めて帰国した人たちを「中国帰国者」と呼んでいる。 日本政府の統計によると、2021 年 2 月末までに、国費注2)で日本に 永住帰国した中国残留邦人の人数は 6724 人（孤児 2,557 人、婦人 4,167 人) であり、家族を加えると、総数は 20911 人である ${ }^{2)}$ 。 の中、東京、大阪、神奈川は、中国帰国者が最も多い上位 3 都道府 県である。さらに、私費で帰国した中国帰国者は日本全国で約 10 万 人に達すると推測される注3)。本研究は、1975 年以後に帰国し、2020 年現在日本に住む 65 歳以上の一世及び二世中国残留邦人並びにそ の配偶者を「高齢中国帰国者」と定義する(elderly Japanese People from China、以下、 elderly JPC)。
厚生労働省の報告書により、2015 年、中国残留邦人一世の平均年 齢は 76 歳であり、配偶者の平均年齢は 72.6 歳である ${ }^{3)}$ 。また、中 国残留邦人二世も多くは 65 歳以上であり、高齢化の問題がある ${ }^{4)} 。$ ほとんどの中国帰国者は、帰国するまで何十年も中国に住み、文 化背景、生活習慣、社会システムが全く異なる中国から日本一の移 行は彼らに大きな環境変化をもたらした。人間の高齢化プロセスは、 外部環境と身体機能の変化の両方への継続的な適応過程と見な寸こ とができる5)。移行による環境ストレスが彼らの適応力をはるかに 超えると、不適応の問題を引き起こし、「移行ストレス症候群」を生 じる6)

これらの背景から、高齢中国帰国者の移行による環境変化と住環 境を研究することは重要である。高齢中国帰国者が日本社会に適応 し、「エイジング・イン・プレイス」注4) という目標を達成しながら 地域に住み続けるためにまずは現状を把握する必要がある。

\section{2. 既往研究と本研究の位置づけ}

建築学会において中国帰国者を対象とした研究は取り組まれてい ない。なお、高齢のエスニック・マイノリティを対象とした研究は 在日韓国人・朝鮮人の特別養護老人ホームの居住環境に関する研究 のみである 7)。また在日外国人に関する研究は公営団地等のコミュ ニティ形成や居住環境に関する研究があり、在日外国人労働者を対
*1 大阪大学工学研究科地球総合工学専攻 博士後期課程

*2 大阪大学工学研究科地球総合工学専攻 准教授・博士 (工学)

*3 大手前大学建築 ·芸術学部 専任講師 ·博士 (芸術)

*4 大阪大学工学研究科地球総合工学専攻 教授 - 博士 (工学)
Grad. Student, Division of Global Architecture, School of Engineering, Osaka Univ.

Assoc. Prof., Division of Global Architecture, School of Engineering, Osaka Univ., Dr.Eng. Junior Assoc. Prof., Faculty of Architecture and Arts, Otemae Univ., Dr.Art.

Prof., Division of Global Architecture, School of Engineering, Osaka Univ., Dr.Eng. 
象にしている 8) 9) 10)。異文化への環境移行についての研究は、在日 ウイグル族を対象とした異なる住文化への環境移行に伴う住まい方 の変容に関する研究のみである ${ }^{11)}$ 。また、日本人高齢者の環境移行 に関する研究は主に自宅から施設への移行による環境変化及び新し い環境への適応問題である 12) 13)。本研究は中国帰国者の異文化への 環境移行と日本国内の引っ越しによる環境移行に注目寸る。

エイジング・イン・プレイスについて、高齢中国帰国者を対象と した研究を他分野に広げると。熊原ら ${ }^{14)}$ は、中国帰国者に対し日本 に長期的な適応の促進を目指し、か祇てより社会経済的側面、文化 的差異、母文化の保持といった側面からの支援が重要視されてきた と指摘している。王ら 15) は、高齢中国帰国者が安心して老後生活を 送れるように、母語や母国文化、風習や習慣などに配慮し、それを 介護環境のなかに取り入れ、在住外国人高齢者も日本人高齢者と同 質な介護サービスが受けられるように介護環境を整えていく必要が あると指摘している。

本研究において、高齢中国帰国者にとってのエイジング・イン・ プレイスとは、「母語（日本語能力も）や母国文化、風習や習慣な どに配慮する必要性から社会環境も重視しつつ、さらに介護や看取 りも視野に入れながら、人生の終末期にできる限り住み慣れた現在 の自宅や地域での継続した生活を可能にする」と定義する。高齢中 国帰国者の住環境の実態は把握されておらず、建築計画分野から環 境移行(特に居住地の変遷)と住環境に焦点を当てた研究に本研究は 取り組む意義がある。

\section{3. 研究の目的}

本研究の目的は以下の 3 点である。1）高齢中国帰国者の中国か ら日本の現在の家への移行のプロセスを示し、移行によって引き起 こされる環境の変化を明らかにする。2）高齢中国帰国者の住宅環 境、近隣環境及び社会環境（これらをまとめて「住環境」と呼ぶ） を調查し、高齢中国帰国者の住環境の現状を把握する。3）上記の 高齢中国帰国者の環境移行及び住環境実態を把握し、高齢中国帰国 者にとって「エイジング・イン・プレイス」を実現するための基礎 的資料を得る。なお、本研究では、中国残留邦人はその家族および 二世以降の家族単位で来日して日本に在住することが多いことと ${ }^{3} 、$ 高齢中国帰国者の住環境の実態・課題を把握することを目的とする ため、中国残留邦人の一世・二世とその配偶者を高齢中国帰国者と して調査対象とする。

\section{4. 中国帰国者に対する支援政策}

1980 年代から、日本政府は、中国帰国者の生活の安定を目的とし て、いくつかの支援政策を実施してきた。1994 年に「中国残留邦人 等の円滑な帰国の促進及び永住帰国後の自立の支援に関する法律」 が制定され、初めて「国等の責務」が明らかにされた。これまでの 親族・身元引受人中心の援護政策から「援護の社会化」へという大 きな転換を向かえることとなった。2007 年には従来の支援策を改善 するため、「中国残留邦人等の円滑な帰国の促進並びに永住帰国した 中国残留邦人等及び特定配偶者の自立の支援に関する法律」（以下、 「新支援法」) が成立し、2008 年に施行した。なお、中国帰国者の うち二世とその配偶者はこの新支援法の対象外である注5)。

生活支援について、2008 年から帰国前の公的年金に加入できなか
つた期間だけでなく、帰国後の期間についても、特例的に保険料の 納付が認められた。納付に必要な額は全額国が負担することにより、 老齢基礎年金等の満額支給が受けられる。また、中国残留邦人等の 方が亡くなられた後に、支援給付を受けているその配偶者に対して 配偶者支援金を支給する。住宅支援について、国及び地方公共団体 は、中国帰国者の居住の安定を図るため、公営住宅等の供給の促進 に必要な施策を講ずるものとする。多くの都道府県は国費で帰国し た中国帰国者に対する公営住宅の優先入居の取扱いと優先入居枠の 確保、家貨の減免等の住宅支援を実施している。

医療支援について、医療支援給付の範囲や診療方針等については、 基本的に医療扶助の取扱いに準じ、一定の条件で医療費の全額が医 療支援給付の対象となる。日本語が不自由であるなど中国残留邦人 等の特別な事情を踏まえ、手続きに関寸る配慮がある。介護支援に ついて、介護支援給付に関する公費負担以外にも、高齢中国帰国者 が利用する介護事業所や介護施設等を訪問し、中国語による語りか けを行う「語りかけボランティア訪問支援」を中国帰国者支援・交 流センター(全国 7 カ所)が実施している。また、国はこうした帰国 者を支援するために、帰国者事情に通じ中国語が話せる支援・相談 員、自立支援通訳などの派遺事業を行っている。

上記以外の支援政策について、日本一永住帰国を希望する中国残 留邦人等に対して永住帰国旅費や自立支度金を支給する。永住帰国 直後の世帯に対し全国各地の定着促進センターにおいて、6 ケ月間 にわたり基礎的な日本語教育や日本の生活習慣等の研修を実施する。 また、永住帰国した中国残留邦人等及びその親族等の雇用の機会の 確保を図るため、職業訓練の実施、就職のあっせん等必要な施策を 講ずる。

\section{5. 研究の方法}

本研究では、大阪府在住の高齢中国帰国者 18 名を対象に、自宅 とその近隣で現地調查を実施した。また、彼らとその家族に対する アンケートとインタビューを行った。調査者は訪問介護事業所のケ アマネジャーの協力の下で調查を行い、ケアマネジャーと一緒に調 査対象の家に訪問した。調査は、主に中国語を使用した。

対象者の選定では、中国残留邦人の一世・二世とその配偶者の内、 65 歳以上で人生の半分以上を中国に在住していた高齢者の条件の 下、協力が得られた 18 名とした。ケアマネージャーを通して協力 を依頼したため、居住地域は同じではなく、18 名の対象者は大阪府 の 6 市に居住している。そのことにより多様な住環境の結果が得ら れると考えられる。アンケート・インタビューの内容を Table1 に示 す。調查期間は 2019 年 11 月から 2020 年 08 月である。

Table1 The outline of the survey

\begin{tabular}{|c|c|c|}
\hline \multirow{5}{*}{$\begin{array}{l}\mathrm{Q} \text { and } \mathrm{I} \\
\text { survey }\end{array}$} & Purpose & $\begin{array}{l}\text { Master the basic characteristic of the } 18 \text { elderly JPC. Understand their current } \\
\text { status of daily life and past life stories. }\end{array}$ \\
\hline & Subjects & The 18 elderly JPC and their family members. \\
\hline & Contents & $\begin{array}{l}\text { Age, nursing levels, family members, national identity, social connections, } \\
\text { home activities, frequency of going out, relocation time and frequency, reasons } \\
\text { of relocation, the living environment details in China, the past life stories, etc. }\end{array}$ \\
\hline & Method & $\begin{array}{l}\text { Taking questionnaires and interviews for the } 18 \text { elderly JPC, and if they had } \\
\text { difficulties in completing the survev, their family members would support help. }\end{array}$ \\
\hline & Time & 2019.11-2021.08(average time of one survey is 2 hours) \\
\hline \multirow{5}{*}{$\begin{array}{l}\text { Field } \\
\text { survey }\end{array}$} & Purpose & $\begin{array}{l}\text { Master the basic information of the elderly JPC's houses and understand the } \\
\text { neighborhood environment. }\end{array}$ \\
\hline & Subjects & The 18 elderly JPC's homes and their community neighborhood. \\
\hline & Contents & $\begin{array}{l}\text { The housing type, size, plan layout, barrier-free condition, etc. The convenience } \\
\text { in neighborhood and the places they usually go like parks, supermarkets, etc. }\end{array}$ \\
\hline & Method & Taking photos, measurement, drawing, recording. \\
\hline & Time & 2019.11-2021.08 (the average time of one field survey is 2 hours) \\
\hline
\end{tabular}


Table2 The basic information of 18 Japanese People from China

\begin{tabular}{|c|c|c|c|c|c|c|c|c|c|c|c|c|c|}
\hline \begin{tabular}{|l|}
$\begin{array}{l}\text { Subjects' } \\
\text { number }\end{array}$ \\
\end{tabular} & Gender & Age & $\begin{array}{l}\begin{array}{l}\text { Nursing } \\
\text { care level }\end{array} \\
\end{array}$ & Nationality & \begin{tabular}{|l|}
$\begin{array}{l}\text { National } \\
\text { identity }\end{array}$ \\
\end{tabular} & Generation & \begin{tabular}{|l} 
Years \\
in Japan
\end{tabular} & $\begin{array}{l}\text { Years in } \\
\text { current home }\end{array}$ & $\begin{array}{l}\text { Live alone or with family } \\
\text { members }\end{array}$ & Japanese level & Education level & $\begin{array}{l}\text { Jobs in } \\
\text { China }\end{array}$ & $\begin{array}{l}\text { Jobs in } \\
\text { Japan } \\
\end{array}$ \\
\hline \begin{tabular}{|l|l}
{$[1]$} & 1 \\
\end{tabular} & Female & 97 & Care 5 & Japan & Japanese & 1st Generation & 25 & 18 & Alone & Well & Junior high school & Farmer & Jobless \\
\hline [2] & Male & 71 & Care 2 & China & Chinese & 2nd Generation & 23 & 8 & wife & A little & Junior high school & Doctor & Factory \\
\hline$[3]$ & Female & 88 & Care 2 & Japan & Japanese & 1st Generation & 25 & 6 & Alone & Not well & Primary school & Farmer & Jobless \\
\hline$[4]$ & Female & 91 & Care 2 & China & Japanese & 1st Generation & 30 & 7 & Alone & Not well & Primary school & Employee & Jobless \\
\hline$[6]$ & Female & 68 & Care 4 & China & Chinese & Spouse of 2nd Generation & 10 & 9 & Husband and son's family & Cannot & Primary school & Farmer & Jobless \\
\hline$[7]$ & Female & 80 & Care 2 & China & Chinese & 1st Generation & 28 & 7 & Alone & A little & High school & Employee & Jobless \\
\hline$[8]$ & Male & 73 & Care 3 & China & Chinese & 2nd Generation & 24 & 4 & wife & Cannot & Illiteracy & Farmer & Factory \\
\hline [9] & Male & 81 & Care 2 & China & Chinese & 2nd Generation & 12 & 2 & Alone & Cannot & Illiteracy & Farmer & Jobless \\
\hline [10] & Male & 76 & Care 2 & China & Chinese & 2nd Generation & 25 & 3 & wife & A little & Primary school & Farmer & Jobless \\
\hline$[12]$ & Male & 80 & Care 3 & China & Chinese & 1st Generation & 24 & 24 & wife & Cannot & Junior high school & Employee & Jobless \\
\hline$[13]$ & Female & 80 & Care 3 & China & Chinese & Spouse of 1st Generation & 25 & 25 & Alone & Cannot & Primary school & Jobless & Jobless \\
\hline [14] & Male & 71 & Support 2 & China & Chinese & 2nd Generation & 23 & 6 months & Wife & Cannot & Primary school & Farmer & Factory \\
\hline [15] & Female & 86 & Care 2 & China & Chinese & Spouse of 1st Generation & 30 & 7 & Son & Not well & University & Teacher & Factory \\
\hline [16] & Female & 66 & Care 1 & China & Chinese & Spouse of 2nd Generation & 20 & 1 & Husband & Cannot & Illiteracy & Farmer & Factory \\
\hline [17] & Female & 67 & Care 1 & China & Chinese & 2nd Generation & 31 & 6 & Daughter's family & Not well & Junior high school & Employee & Factory \\
\hline$[18]$ & Female & 76 & Care 2 & China & Chinese & 2nd Generation & 19 & 11 & Alone & Well & Junior high school & Jobless & Jobless \\
\hline
\end{tabular}

\section{6. 倫理的配慮}

本研究では、中国帰国者らが抱える言語の問題に配慮しながら、 説明や調查は文言を吟味して中国語で行った。研究の趣旨、調査へ の参加は自由意思で決定でき、断っても不利益を受けることは一切 ないこと、匿名性は保持されることについて対象者に、口頭および 文書を用いて説明し、これらを厳守した。調査票の提出をもって研 究協力への同意とみなした。

\section{7. 結果}

\section{1 研究対象の属性}

18 人の対象者の属性を Table 2 に示す。対象者 18 人のうち、女 性が 11 人、男性が 7 人、一世が 5 人、一世の配偶者が 2 人、二世 が 9 人、二世の配偶者が 2 人である。平均年齢は 77 歳で、最年少 が 65 歳、最高齢が 97 歳である。平均要介護度は要介護 2.2 である。 日本国籍に変更した人は 2 人で、 16 人は中国国籍を保留したまま日 本の永住権または定住ビザを持っている。ナショナル・アイデンテ イティは 3 人のみが日本人で、15 人は自分が中国人だと思ってい る。日本在住の平均年数は 22.7 年であり、現在の家の居住平均年数 は 8.8 年である。 7 人がひとりで暮らし、それ以外の人が配偶者ま たは子供の家族と同居している。

日本語能力について、3 人は日常会話が問題ない程度で、それ以 外はゆっくりであれば不自由なく会話が可能なレベルからできない レベルまでさまざまである (Fig.1)。教育歴について、4 人は学校で 教育を受けたことがなく、6 人が小学校卒業まで、 7 人は中学校ま たは高校卒業まで、大学卒業は 1 人であった。中国在住時、9 人が 農民、 2 人が無職であり、比較的低所得の人が多かった注6) (Fig.2)。 日本に来た後、 10 人が仕事をしていなく、 8 人が工場で働いていた。

\section{2 現在までの環境移行のプロセス}

対象者の現在までの環境移行のプロセスと環境移行の原因を Fig. 3 に示寸。対象者の来日時の平均年齢は 56 歳であった。日本で

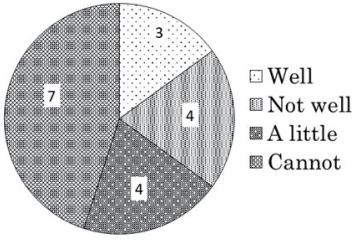

Fig.1 Japanese level of 18 elderly JPC

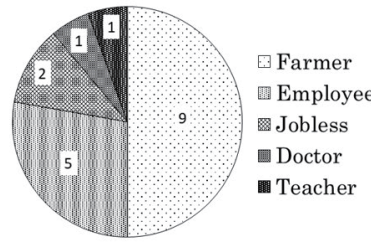

Fig.2 Jobs did in China of 18 elderly JPC
の居住年数の最長の人が 31 年で、最短の人が 10 年である。現在の 家の居住年数の平均は 8.8 年で、最短の人が 6 ヶ月である。

対象者のうち、3 人が日本で生まれ、9人が中国東北部の省（黒竜 江省、吉林省、遼寧省) 、 2 人が福建省、 1 人が四川省、 1 人が山東 省、 1 人が上海市で生まれた。全員が 1980 年代以降に来日した。平 均の引っ越し回数は 2 回で、最多の人は 4 回であった。 3 人のみが 来日後の引つ越しがなかった。引つ越しした理由の上位 3 つは、公 営住宅の当選、子供たちとの別居、子供たちのキャリアの昇進であ った。公営住宅の当選について、前述のように新支援法は中国帰国 者一世とその配偶者に対し公営住宅の優先入居の支援政策を実施し ているが、二世は日本人と同じく低所得者向けの公営住宅の居住は 抽選が原則である。子供たちとの別居について、多くの対象者は、 来日後子供と同居していたが、生活が安定した後別居を選択した。 また、小さい孫や孫娘を世話するため子供の家族と同居する対象者 もいたが、孫や孫娘が中学生になると、子世帯と別居を選択した場 合もあった。子供たちのキャリアの昇進とは、対象者は子供と同じ 都市に住みたいため、子供が仕事のため他の都市に引っ越しする場 合、彼らもその都市に引っ越しすることである。

\section{3 住宅環境}

\section{1）住宅の基本情報}

対象者の住宅情報をTable3 に示す。12 人の対象者は市営住宅や 府営住宅の公営住宅に住んでいる。家賃が安い木質文化住宅や賃貸 アパートに各 2 人が住み、 2 人は子供世代と戸建住宅に住んでいる。 平面配置について、14 人はリビングルームがない $2 \mathrm{~K} 、 2 \mathrm{DK} 、 3 \mathrm{~K}$ な

Table3 The basic housing information of 18 elderly JPC

\begin{tabular}{|l|l|l|l|l|l|l|}
\hline $\begin{array}{l}\text { Subjects' } \\
\text { number }\end{array}$ & Housing type & $\begin{array}{l}\text { Plan } \\
\text { layout }\end{array}$ & Area & $\begin{array}{l}\text { Living story } \\
\text { Stories }\end{array}$ & Built time & $\begin{array}{l}\text { Barrier } \\
\text { free }\end{array}$ \\
\hline$[1]$ & Row house & $2 \mathrm{~K}$ & $30 \mathrm{~m}^{2}$ & $1 / 2$ & Unknown & Yes \\
\hline$[2]$ & Row house & $2 \mathrm{~K}$ & $37 \mathrm{~m}^{2}$ & $1 / 2$ & 1970 & No \\
\hline$[3]$ & Rental Apartment & $2 \mathrm{~K}$ & $39 \mathrm{~m}^{2}$ & $3 / 8$ & 1989 & Yes \\
\hline$[4]$ & Municipal house & $2 \mathrm{Dk}$ & $48 \mathrm{~m}^{2}$ & $1 / 15$ & 1989 & Yes \\
\hline$[5]$ & Prefectural house & $2 \mathrm{~K}$ & $36 \mathrm{~m}^{2}$ & $4 / 11$ & 1994 & No \\
\hline$[6]$ & Detached house & $4 \mathrm{LDK}$ & $108 \mathrm{~m}^{2}$ & $1 / 4$ & Unknown & No \\
\hline$[7]$ & Municipal house & $3 \mathrm{DK}$ & $58 \mathrm{~m}^{2}$ & $4 / 15$ & 1995 & No \\
\hline$[8]$ & Prefectural house & $3 \mathrm{DK}$ & $62 \mathrm{~m}^{2}$ & $20 / 31$ & 1999 & No \\
\hline$[9]$ & Municipal house & $3 \mathrm{~K}$ & $39 \mathrm{~m}^{2}$ & $4 / 15$ & 1972 & No \\
\hline$[10]$ & Prefectural house & $2 \mathrm{~K}$ & $36 \mathrm{~m}^{2}$ & $3 / 5$ & 1977 & No \\
\hline$[11]$ & Municipal house & $3 \mathrm{~K}$ & $42 \mathrm{~m}^{2}$ & $8 / 12$ & 1998 & No \\
\hline$[12]$ & Prefectural house & $2 \mathrm{DK}$ & $38 \mathrm{~m}^{2}$ & $2 / 5$ & 1977 & Yes \\
\hline$[13]$ & Municipal house & $3 \mathrm{DK}$ & $62 \mathrm{~m}^{2}$ & $3 / 9$ & 1995 & Yes \\
\hline$[14]$ & Rental Apartment & $2 \mathrm{LDK}$ & $53 \mathrm{~m}^{2}$ & $1 / 3$ & 1997 & No \\
\hline$[15]$ & Municipal house & $3 \mathrm{DK}$ & $54 \mathrm{~m}^{2}$ & $8 / 14$ & Unknown & Yes \\
\hline$[16]$ & Municipal house & $3 \mathrm{DK}$ & $48 \mathrm{~m}^{2}$ & $4 / 9$ & 1982 & No \\
\hline$[17]$ & Detached house & $4 \mathrm{LDK}$ & $120 \mathrm{~m}^{2}$ & $1 / 2$ & 2014 & No \\
\hline$[18]$ & Municipal house & $2 \mathrm{LDk}$ & $59 \mathrm{~m}^{2}$ & $1 / 7$ & 2010 & Yes \\
\hline
\end{tabular}




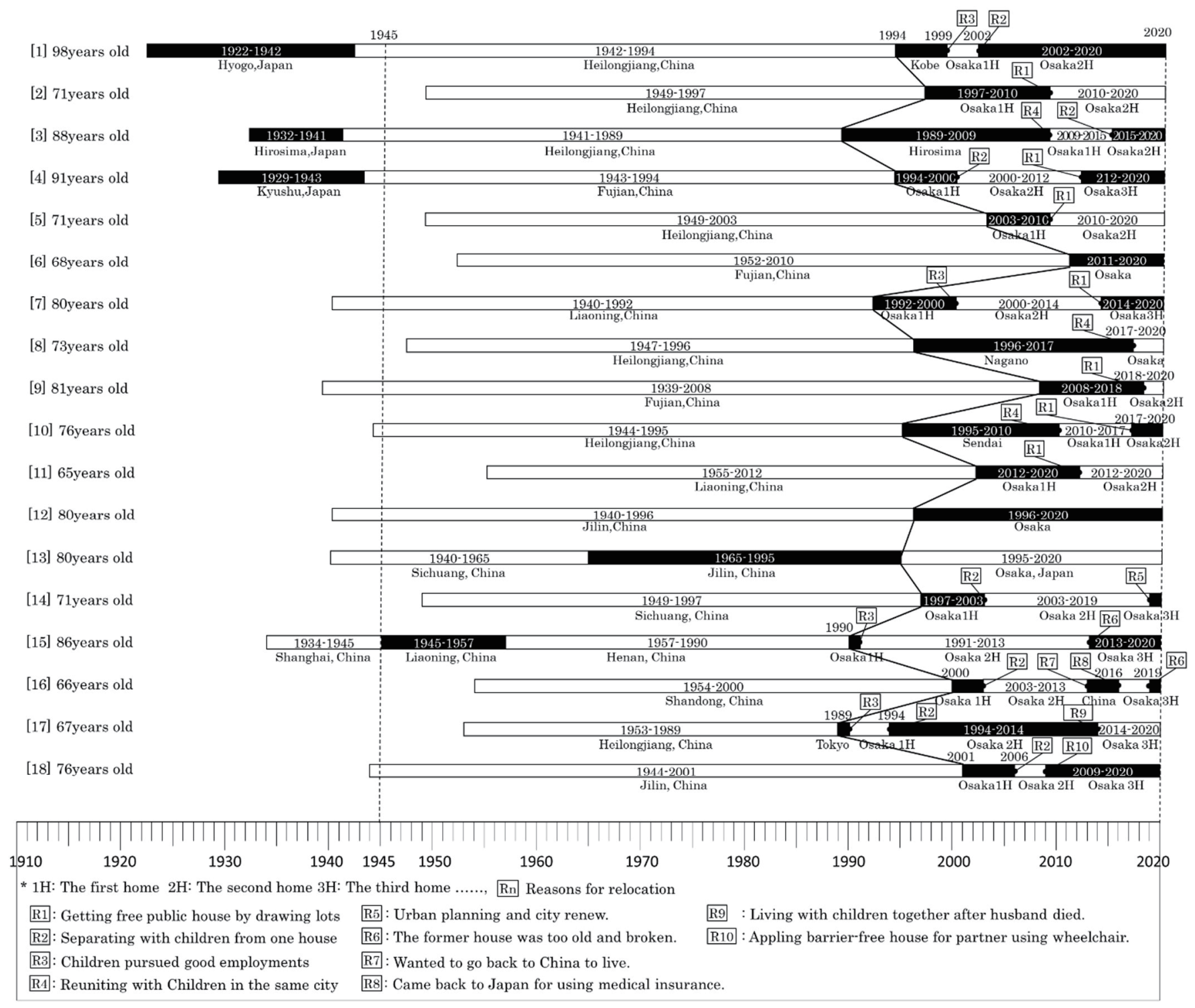

Fig.3 The specific relocation processes and reasons of the 18 research objects

どの類型であり、毎日の活動はすべて寝室やキッチン/ダイニングル 一ムで行われる。

住宅の平均面積は $53 \mathrm{~m}^{2}$ で、大多数の住宅の面積が $60 \mathrm{~m}^{2}$ 以下であ る。住む階数は、8 人の対象者が 2 階以下に住み、 7 人の対象者が 3-5 階に住み、11 階以上に住む人が 1 人だけである。そのうち、4 人の住宅が 1970 年代に建てられた。また、半分以上の対象者の住 宅はバリアフリー設備がない。

\section{2 ) 家でよく使っている生活用品}

物品には「記号」として働く「付加価值」（自己提示的価值、関係 性の象徵的価值、情緒的価值)が備わっており、物品は自己アイデン

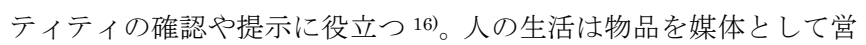
まれることが多く、人と物品の間には相互の浸透関係があり、平常 時において両者は安定した居住環境システムを構築している ${ }^{16)}$ 。高 齢中国帰国者にとって、よく使っている生活用品は彼らの在宅生活 の質を反映していると考えられ、Tabale4 に自宅で使用している家 具・生活道具等を示す。

睡眠や食事などの生活必需品について、18 人のうち住宅の広さ
にかかわらず、 17 人の対象者は毎日ベッドで寝ていて、床で寝て いる対象者が 1 人のみである。1 13 人の対象者は家にテーブルが一

Table4 The furniture and living goods at home of 18 elderly JPC

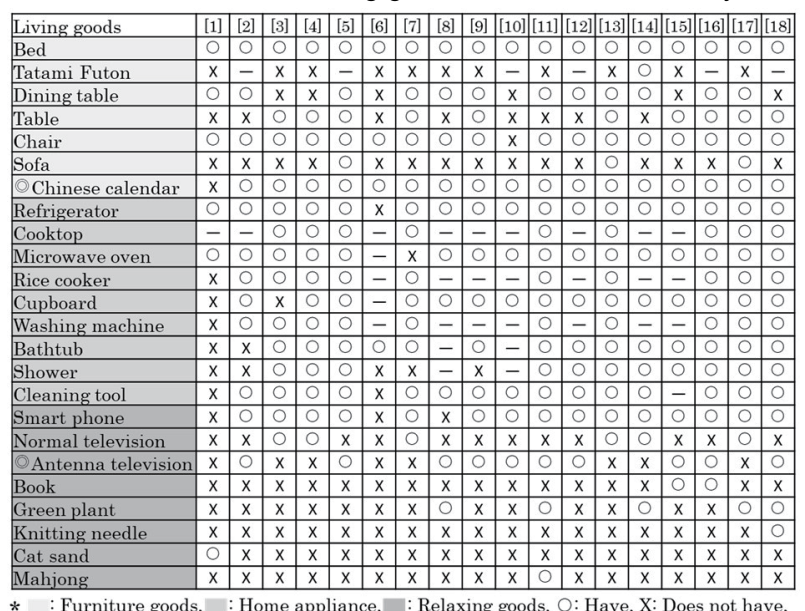

* : Furniture goods, : Home appliance, : Relax 
点のみあり、このテーブルは全て椅子座のテーブルで、主に食卓と して使用されている。台所用品については、ほとんどの対象者の家 に冷蔵庫、電子レンジ、炊飯器などの調理家電があるが、要介護度 の影響により、8 人が一部の調理家電を使わなく、訪問介護員また は子供が利用している。また、すべての対象者が中国のカレンダー を使っている、その理由は主な中国の祝日が農暦（日本の旧暦）の 祝日で、中国のカレンダーには農暦と西暦両方を記載しているから である。リラックス用品について、16 人はテレビがあり、11 人が テレビを寝室に置いている。そのうち 10 人が衛星放送のアンテナ を設置し、中国のテレビ放送を視聴している。また、5 人がスマー トフォンを所有し、これを使って中国の新聞やビデオを見ている。 室内でよく使っている生活用品の量や種類別数と彼らの身体状況 の間に明確な関係性がある、特に台所、掃除とリラックス用品であ る。よく使っている生活用品の量や種類別数が多いほど、彼らの自 立度が高く、日常生活動作が他人への依頼性が低く、生活の質が高 いことを反映している。また、敷布団ではなくべッドに寝ることや 座布団ではなく椅子に座ることを選ぶこと、中国のカレンダーと中
国のテレビを見ることから、彼らは今でも中国式の生活習慣を維持 していると考えられる注7)。

3) 在宅の日常活動と在宅ライフスタイル

Fig.4 に自宅での活動を示す。対象者が家で最も多く行う活動は 簡単な家事である。最も多く行う娛楽は中国のドラマを見ることで ある。家で簡単な運動をする対象者は 3 人、ペットを飼っている人 は 1 人であった。室内の空間の使用状況と日常活動を Fig.5に示す。

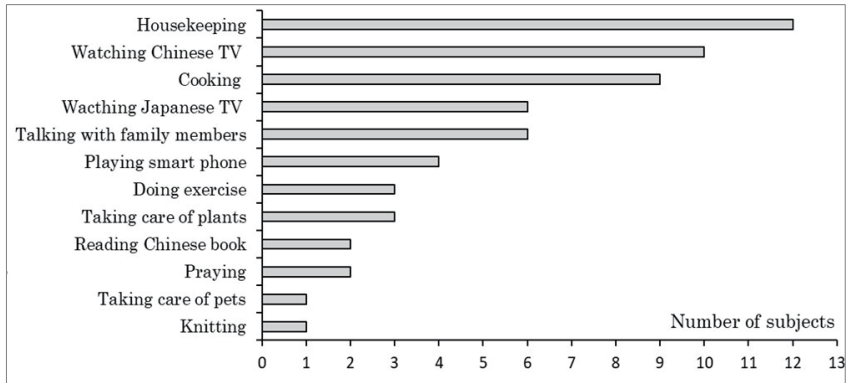

Fig.4 Daytime activities of 18 elderly JPC at home

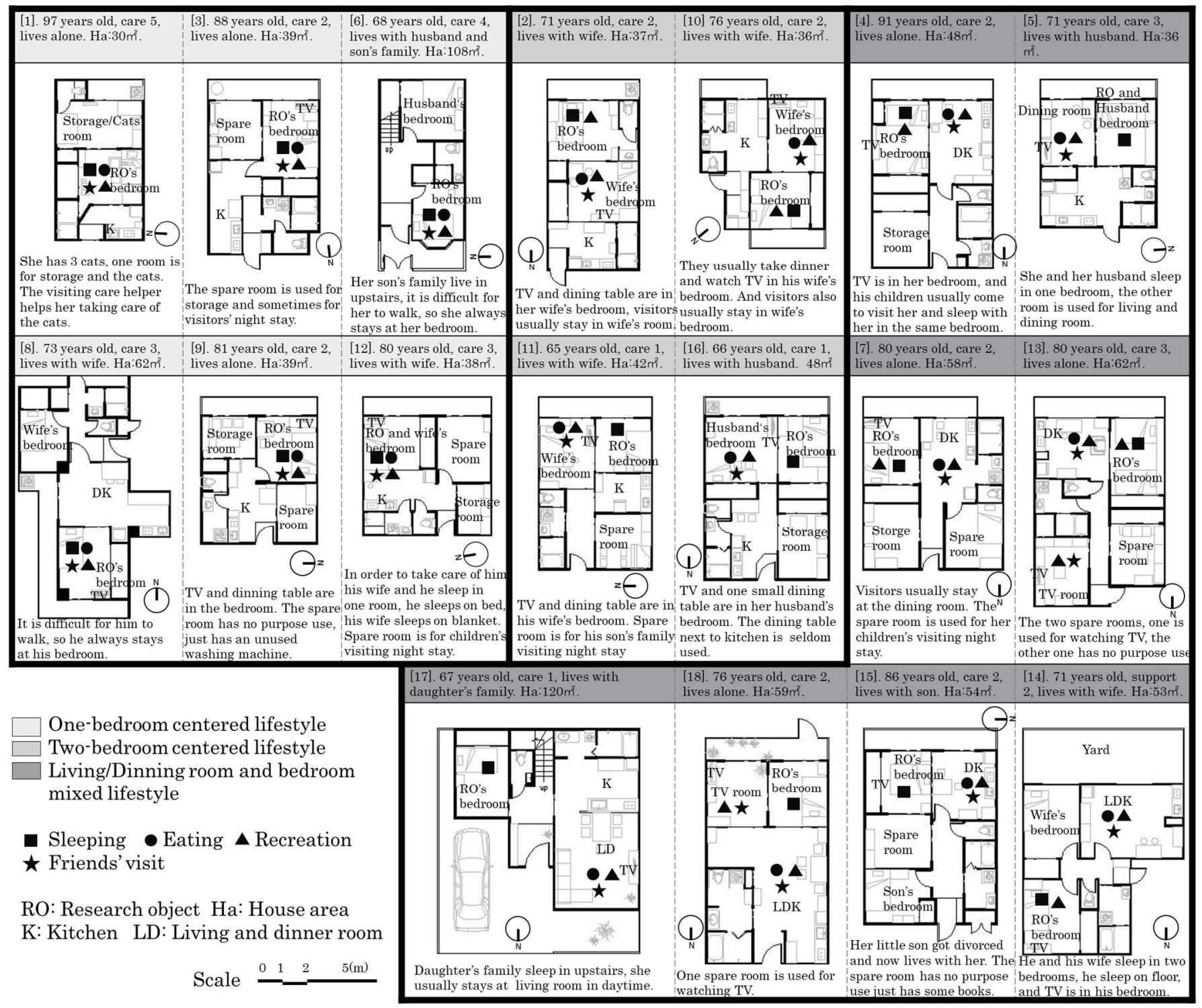

Fig.5 The 3 types of home lifestyle of 18 elderly Japanese people from China 
18 人の対象者の在宅ライフスタイルは、 1 ベッドルーム中心 $(6$ 人) 2 ベッドルーム中心(4 人)、ベッドルームとリビング・ダイニングル ーム混在 (8人)の 3 タイプに分類できる（Fig.5）。

1 ベッドルーム中心のライフスタイルでは、高齢者がほとんどの 時間を一つのベッドルームで過ごし、睡眠、食事、リラックスなど の日常活動をベッドルームで行う。 2 ベッドルーム中心のライフス タイルでは、彼らの日常活動を通常二つのベッドルームで行う。ベ ッドルームとリビング・ダイニングルームのライフスタイルでは、 高齢者は通常ベッドルームで寝るが、それ以外の時間はリビング・ ダイニングルームに滞在する。要介護度との関係を見ると、要介護 4 以上の 2 人は 1 ベッドルーム中心のライフスタイルである。

\section{4 ) 住宅環境に対する満足度}

住宅環境の満足度について、満足が 7 人、やや満足が 6 人、やや 不満足が 4 人、不満足が 1 人の回答であった。その理由について、 多くの対象者が生活水準や経済状況が低い当時の中国の住宅状況と 現在の住宅状況を比べて良くなったことや家貨が低額であることを 挙げている。

不満足または生活上の不便な点を Fig.6に示す。「バリアフリーで ない」が最も多く、次いで、「空間が狭い・リビングルームがない」 「クローズドキッチンではない」古すぎる」「大きい声が出せない」 の順である。「バリアフリーでない」については、対象者が介護に係 るリフォームの助成について情報を知らないためである。介護保険 や自治体の助成金制度により申請すれば住宅の改修にかかる費用が 最大 20 万円まで、1割の自己負担で利用できるが、この情報を把 握していない。「クローズドキッチンではない」について、ほとんど の対象者は毎日中国料理を作っているので油煙が強く、換気性能が 不足し、湯煙が部屋に充満するためである。

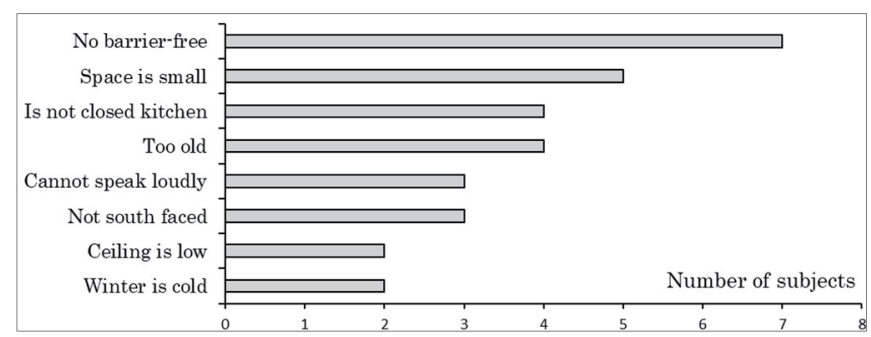

Fig.6 The dissatisfied points of houses of 18 elderly JPC

\section{4 社会環境}

社会環境とは、高齢者の社会的つながりと参加する社会活動を指 す。Bekhet, A. K.の研究によると、社会活動に参加し、社会的つな がりを維持または増やしている高齢者は、孤立した高齢者よりも健 康レベルの低下の進行が遅いことが明らかにされた 17 。 社会的資源 との接触を失ったり、社会活動に参加する意欲を失ったりすること は「社会的孤立」と定義できる。社会的孤立に苦しむ人々は通常健 康状態が悪い。社会的孤立がメンタルヘルス、身心の苦痛、認知症、 自殺、早死と関連している可能性があるとの研究結果も得られてい る 18)。

Table 5 は、18 人の対象者の全ての社会的つながりを示してい る。対象者の社会的つながりにおいてはスーパーや飲食店の店員の 一部を除き中国語でコミュニケーションしている。高齢中国帰国者
Table5 The social relationships of 18 elderly JPC

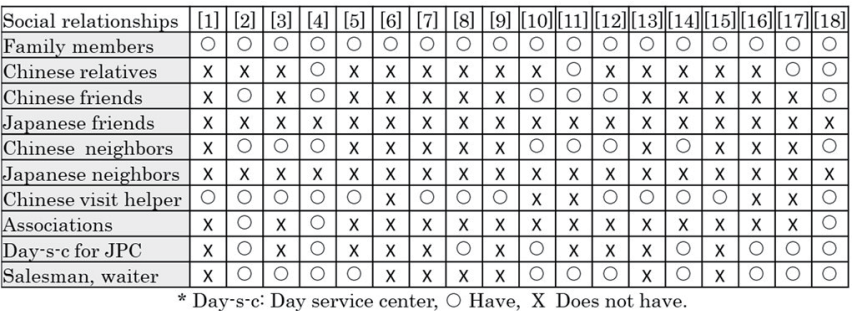

は日本人の友達がつくれず、日本人の隣人と交流がない。中国人や 中国帰国者の隣人との社会的つながりを持つ人が 8 人いる。 3 人の 対象者がかつて日本人向けのデイサービスセンターに行っていたが、 日本語の環境に適応できず、最終的に中国帰国者向けのデイサービ スセンターに行くようになった湦8)。

Mari Smith ${ }^{19)}$ の研究によると、対象者の社会的つながりは親密さ に基づいて 5 つの次元に分けることができ、これを参考に 18 人の 対象者の社会的次元を Fig.7 に示す。対象者の社会的つながりのう ち、家族が最も近い関係である。最も遠い関係である買い物する時 の営業員や飲食店の店員などの見知らない人との交流は、日本社会 への参加度を表している。Table5 に示すように、18 人の対象者の 中で最も多い社会的なつながりは家族であり、全員が該当する。最 も少ない社会的なつながりはアソシエーション（日本語クラス、教 会）での社会的つながりであり、3 人であった。

Fig.8に示すように、社会的つながりの次元と種類を組み合わて、 18 人の対象者の社交程度を強い、やや強い、やや弱い、弱いの 4 つ のレベルに分類した。より多くの次元と種類の社会的つながりを持 っている高齢者は、より強い社交程度を持っている。

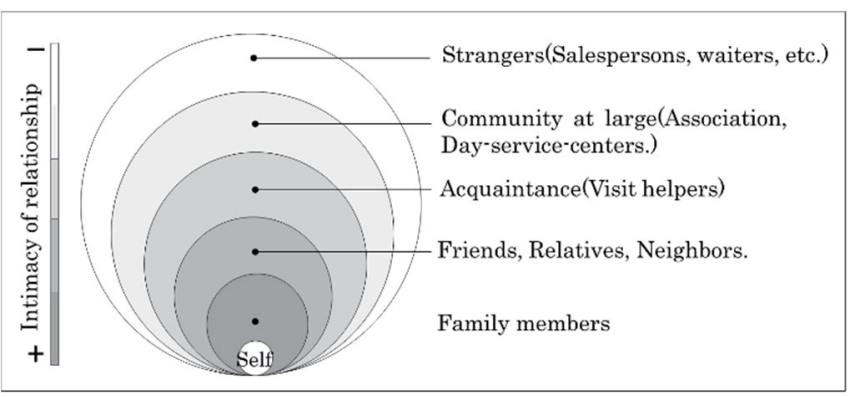

Fig.7 The 5 dimensions of 18 elderly JPC's social relations

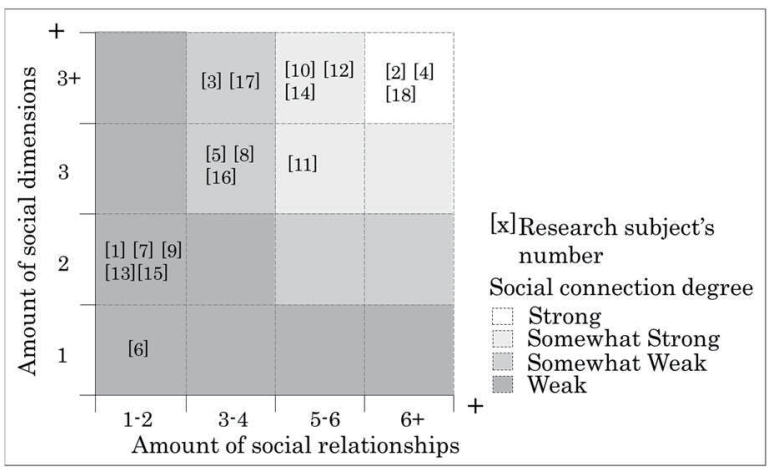

Fig.8 The schematic diagram of social connection degree of 18 elderly JPC 
社交程度が弱い対象者は 6 人いて、家族と中国語を話すへルパー の 2 次元までであり、家族や中国語を話すへルパー以外の社会的つ ながりがない。 5 人の対象者の社交程度はやや弱いであり、彼らの 社会的つながりの次元は 3 以上であるが、 5 人とも介護に関して、 中国語を話すへルパーか中国帰国者向けのデイサービスの一方か、 もしくは両方に社会的つながりを持っている。それ以外の社会的つ ながりが少ない。 3 人の対象者の社交程度は強く、親戚はいないが、 家族や友人、アソシエーション、デイサービスや見知らない人と社 会的つながりがある。4 人の対象者の社交程度はやや強く、家族、 親戚、友人、隣人、アソシエーション等社会的つながりを持ってい る。

\section{5 近隣環境}

\section{1 ) 近隣環境の生活利便性}

近隣環境の範囲を高齢者の身体機能に配して、彼らの自宅から半 径 $500 \mathrm{~m}$ で、徒歩 10 分程度のエリアと定義し、調查対象者の近隣環 境での活動状況を示す。「エイジング・イン・プレイス」を実現する ために高齢中国帰国者にとって、身体機能が低下していっても、近 隣環境の生活利便性が充実し、アクセスできることが重要である。

公共交通、買い物、医療・福祉施設、交友・レクリエーションの 公園注 9) 等の生活利便性について評価する。グーグルマップ (Google map）という地理的情報ならびに現地調查を用いて、18 人の対象者 の家から半径 500 m範囲内の生活利便施設を調査した結果をTable6 に示す。

近隣の生活施設の数量をみると、 18 人の対象者のうち、対象者 $[2]$ ［3］［11］［13］［18］の近隣環境の生活利便性が高く、対象者 [10］ [12］［17］の生活利便性が低い。

\section{Table6 The living facilities in neighborhood of 18 elderly JPC}

\begin{tabular}{|c|c|c|c|c|c|c|c|c|c|c|c|c|c|c|c|c|c|c|}
\hline $\begin{array}{l}\text { The factors of } \\
\text { neighborhood }\end{array}$ & [1] & [2] & [3] & [4] & [5] & [6] & [7] & [8] & [9] & & & & & & & & & \\
\hline Train station & 0 & $\mathrm{x}$ & 0 & 0 & 0 & 0 & 0 & $x$ & $x$ & $x$ & 0 & $\mathrm{x}$ & 0 & $x$ & $\mathrm{x}$ & 0 & $x$ & $x$ \\
\hline Bus station & 0 & $\mathrm{x}$ & $\mathrm{x}$ & 0 & 0 & 0 & 0 & 0 & 0 & 0 & 0 & 0 & 0 & 0 & 0 & 0 & 0 & $\mathrm{x}$ \\
\hline \begin{tabular}{|l|} 
Convenience store \\
\end{tabular} & 0 & 0 & 0 & $\mathrm{x}$ & 0 & 0 & 0 & 0 & $\mathrm{x}$ & $x$ & 0 & $\mathrm{x}$ & 0 & 0 & 0 & 0 & $x$ & 0 \\
\hline Supermarket & 0 & 0 & 0 & 0 & 0 & 0 & 0 & 0 & 0 & $x$ & 0 & \begin{tabular}{|ll}
$x$ \\
\end{tabular} & 0 & 0 & 0 & 0 & $\mathrm{x}$ & 0 \\
\hline \begin{tabular}{|l|} 
Chinese product store \\
\end{tabular} & $x$ & 0 & $\mathrm{x}$ & $\mathrm{x}$ & $\mathrm{x}$ & $\mathrm{x}$ & $\mathrm{x}$ & $\mathrm{x}$ & $\mathrm{x}$ & $x$ & $\mathrm{x}$ & $\mathrm{x}$ & $\mathrm{x}$ & 0 & $\mathrm{x}$ & $\mathrm{x}$ & $\mathrm{x}$ & 0 \\
\hline Restaurant & 0 & 0 & 0 & $\mathrm{x}$ & 0 & 0 & 0 & 0 & 0 & 0 & 0 & 0 & 0 & $\mathrm{x}$ & 0 & 0 & $\mathrm{x}$ & 0 \\
\hline Hospital & 0 & $\mathrm{x}$ & $\mathrm{x}$ & $\mathrm{x}$ & $x$ & $x$ & $x$ & $x$ & $x$ & $x$ & $x$ & $x$ & $x$ & $x$ & 0 & $\mathrm{x}$ & $x$ & $x$ \\
\hline Clinic & 0 & 0 & 0 & 0 & 0 & 0 & 0 & 0 & 0 & $x$ & 0 & $x$ & 0 & 0 & 0 & 0 & $x$ & 0 \\
\hline Street & $x$ & 0 & 0 & $x$ & 0 & 0 & 0 & 0 & 0 & 0 & 0 & 0 & 0 & 0 & 0 & 0 & $x$ & 0 \\
\hline \begin{tabular}{|l|} 
Neighl \\
Distric
\end{tabular} & $x$ & 0 & 0 & $x$ & $x$ & $x$ & $x$ & 0 & 0 & $x$ & 0 & $x$ & 0 & $x$ & $x$ & 0 & 0 & 0 \\
\hline Frien & $x$ & 0 & 0 & 0 & $\mathrm{x}$ & $x$ & $x$ & $x$ & $x$ & 0 & 0 & 0 & $x$ & $x$ & $x$ & $x$ & 0 & 0 \\
\hline $\begin{array}{l}\text { Children's or } \\
\text { relatives' home }\end{array}$ & $x$ & 0 & 0 & 0 & $x$ & 0 & $x$ & $x$ & 0 & 0 & 0 & $x$ & 0 & $x$ & $x$ & $x$ & 0 & 0 \\
\hline Numb & 7 & 9 & 9 & 6 & 7 & 8 & 7 & 7 & 7 & 5 & 10 & 4 & 9 & 6 & 7 & 8 & 4 & 9 \\
\hline $\begin{array}{l}\text { Neighborhood } \\
\text { convenience }\end{array}$ & M & $\mathrm{H}$ & $\mathrm{H}$ & $\mathrm{M}$ & $\mathrm{M}$ & $\mathrm{M}$ & $\mathrm{M}$ & $\mathrm{M}$ & $\mathrm{M}$ & $\mathrm{L}$ & $\mathrm{H}$ & $\mathrm{L}$ & $\mathrm{H}$ & $\mathrm{M}$ & $\mathrm{M}$ & $\mathrm{M}$ & $\mathrm{L}$ & $\mathrm{H}$ \\
\hline
\end{tabular}

\section{2 ) 外出頻度、近隣での活動とコミュニティーライフスタイル}

対象者の近隣での主な行動と 1 週間の外出頻度を Table7 に示す。 7 人の対象者が週に 5 回以上出かけ、 7 人が週に 3 回未満の外出で ある。最も多くの外出が散歩であり、隣人への訪問は 8 人、子ども や親戚への訪問が 9 人、友人と遊ぶ外出が 7 人であった。外出の頻 度と近隣の行動の多様性に基づいて、近隣のコミュニティライフス タイルを、アクティブ(4 人)、ややアクティブ(3 人)、ややパッシブ (4 人)、パッシブ(7 人)の 4 つのタイプに分類した（Fig.9）。

「アクティブ」タイプとは、高齢者がよく出かけて、他の人と中 国語でコミュニケーションをとり、積極的に活動に参加するという タイプである。「ややアクティブ」タイプとは、高齢者が出かける
Table7 The 18 elderly JPC's behaviors and frequency of going out in neighborhood in one week

\begin{tabular}{|c|c|c|c|c|c|c|c|c|c|c|c|c|c|c|c|c|c|c|}
\hline $\begin{array}{l}\text { Beha } \\
\text { neigh }\end{array}$ & [1] & {$[2]$} & {$[3]$} & [4] & [5] & [6] & [7] & [8] & [9] & [10 & [11] & & & [14] & 15] [ & & & \\
\hline Walking & $\mathrm{x}$ & 0 & 0 & 0 & 0 & $x$ & 0 & $\mathrm{x}$ & 0 & 0 & 0 & 0 & 0 & 0 & $x$ & 0 & 0 & 0 \\
\hline Exercising & $x$ & $x$ & $x$ & $x$ & $x$ & $x$ & $x$ & $x$ & $x$ & $x$ & 0 & $x$ & $x$ & $x$ & $x$ & 0 & $x$ & 0 \\
\hline Shopping & $x$ & 0 & $x$ & 0 & 0 & $x$ & 0 & $x$ & $x$ & 0 & 0 & 0 & $x$ & 0 & $x$ & 0 & 0 & 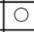 \\
\hline neighbors & $x$ & 0 & 0 & 0 & $x$ & $x$ & $x$ & $x$ & $x$ & 0 & 0 & 0 & $x$ & 0 & $x$ & $x$ & $x$ & c \\
\hline $\begin{array}{l}\text { Visiti } \\
\text { relat }\end{array}$ & $x$ & 0 & 0 & 0 & 0 & $x$ & $x$ & $x$ & $\mathrm{x}$ & $x$ & 0 & $x$ & 0 & 0 & $x$ & $x$ & 0 & \\
\hline Playing w & $x$ & 0 & $x$ & 0 & $x$ & $x$ & $x$ & $x$ & $x$ & 0 & 0 & 0 & $x$ & 0 & $x$ & $x$ & $x$ & \\
\hline 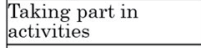 & $x$ & c & $x$ & 0 & $x$ & $\mathrm{x}$ & $x$ & $x$ & $x$ & $x$ & $x$ & $x$ & $x$ & $x$ & $x$ & $x$ & $\mathrm{x}$ & \\
\hline $\begin{array}{l}\text { Going } \\
\text { bath }\end{array}$ & 0 & 0 & 0 & $x$ & $\mathrm{x}$ & 0 & $\mathrm{x}$ & $x$ & 0 & $\mathrm{x}$ & $\mathrm{x}$ & $x$ & 0 & $x$ & $x$ & $x$ & $\mathrm{x}$ & \\
\hline Amount of behaviors & $2^{-}$ & $5+$ & $4-5$ & $5+$ & $2-3$ & 2 & $2-3$ & $2-$ & $2-3$ & $4-5$ & $5+$ & $4-5$ & $2-3$ & $4-5$ & $2^{-}$ & $2-3$ & $2-3$ & \\
\hline $\begin{array}{l}\text { equency } \\
\text { ing out }\end{array}$ & & 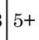 & $5+$ & $5+$ & & & & $2^{-}$ & & & $5+$ & & & & $2^{-}$ & $5+$ & T. & \\
\hline
\end{tabular}

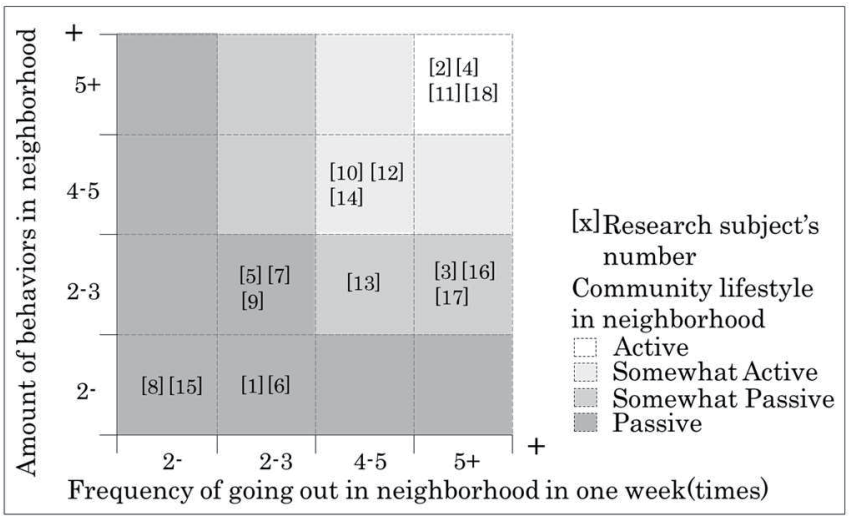

Fig.9 The schematic diagram of community lifestyle of 18 elderly JPC in their neighborhood

ことや他の人とのコミュニケーションが好きであるが、近隣での行 動の多様性や外出の頻度が「アクティブ」タイプより少なくなる夕 イプである。「ややパッシブ」タイプとは、高齢者が買い物や病院に 行くことなど生活に必要な行動以外、外出や他の人とのコミュニケ ーションをしないタイプである。「パッシブ」タイプとは、高齢者が ほとんど外出しなく、他の人とのコミュニケーションがあまりない タイプである。

対象者 [2］［3］［4］らのように、近隣環境に中国語でコミュニケ ーションが取れる友達や家族が住んでいることが外出頻度に影響し ている。１］［6］は要介護度が 4 以上であり、実質外出は困難であ り、介護を受けるためにリハビリテーションやデイサービスを利用 している。[8］１5］は近隣に外出をしていない。近隣に家族や友人 が住んでいないことや、近隣に購買施設があり、歩行能力もあるが 日本語が話せず同居する家族が買い物を行っている。社会的つなが りは家族および中国語を話すへルパーや中国帰国者向けのデイサー ビスだけである。［5］［7］［9］はあまり近隣に外出せず、時々家族 と一緒に外で散歩や買い物をしている。彼らの社会的つながりは家 族及び中国語を話すへルパーや近隣のデイサービスである。

Fig.10 はアクティブタイプの一例である。[18]は 75 歳の中国帰 国者二世の女性であり、ひとりで暮らしている。彼女は 19 年前の 56 歳で来日し、この地域に 11 年間住んでいる。息子 3 人もこの近 くに住んでいる。日本語能力は「well」である。平日、息子の家族 はよく彼女を訪补ている。毎日、彼女は末子の家で晚ご飯を食べて いる。一週間に数回、家の近くの公園で簡単な運動している。この 


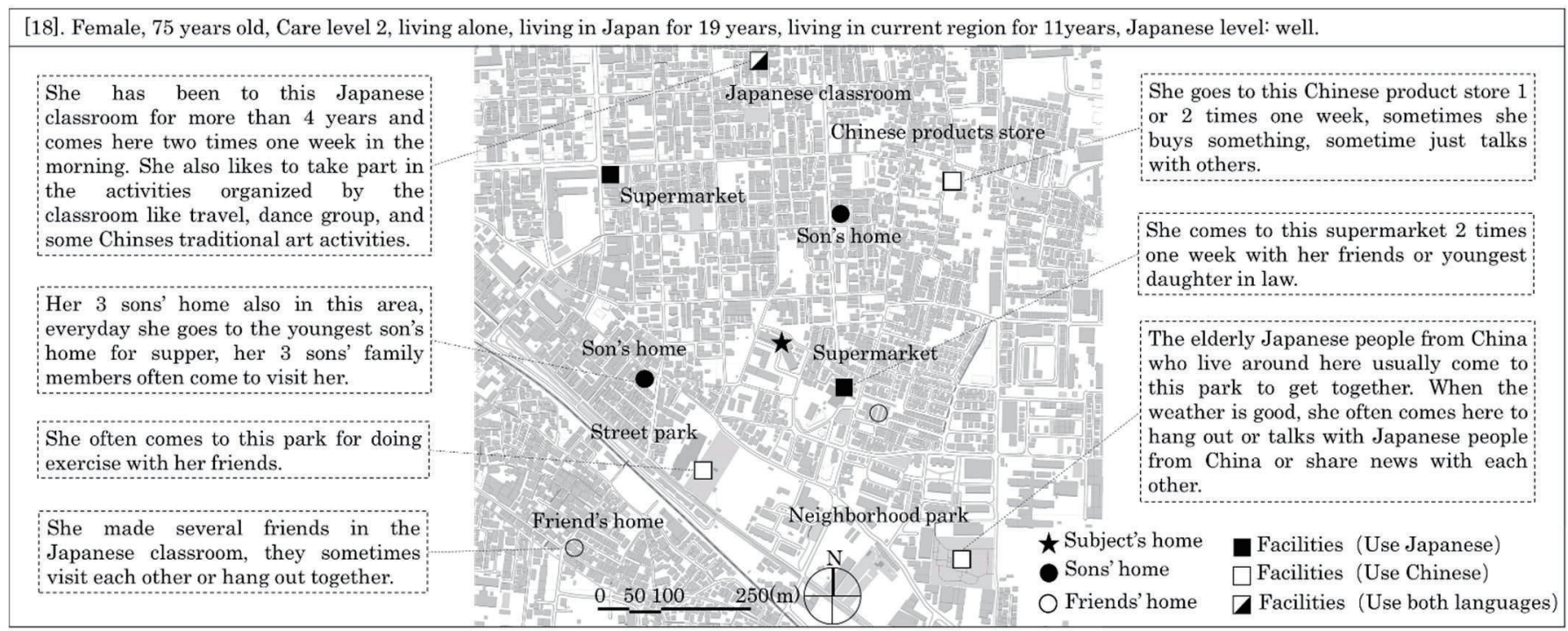

Fig.10 The case description of active type of community lifestyle in neighborhood

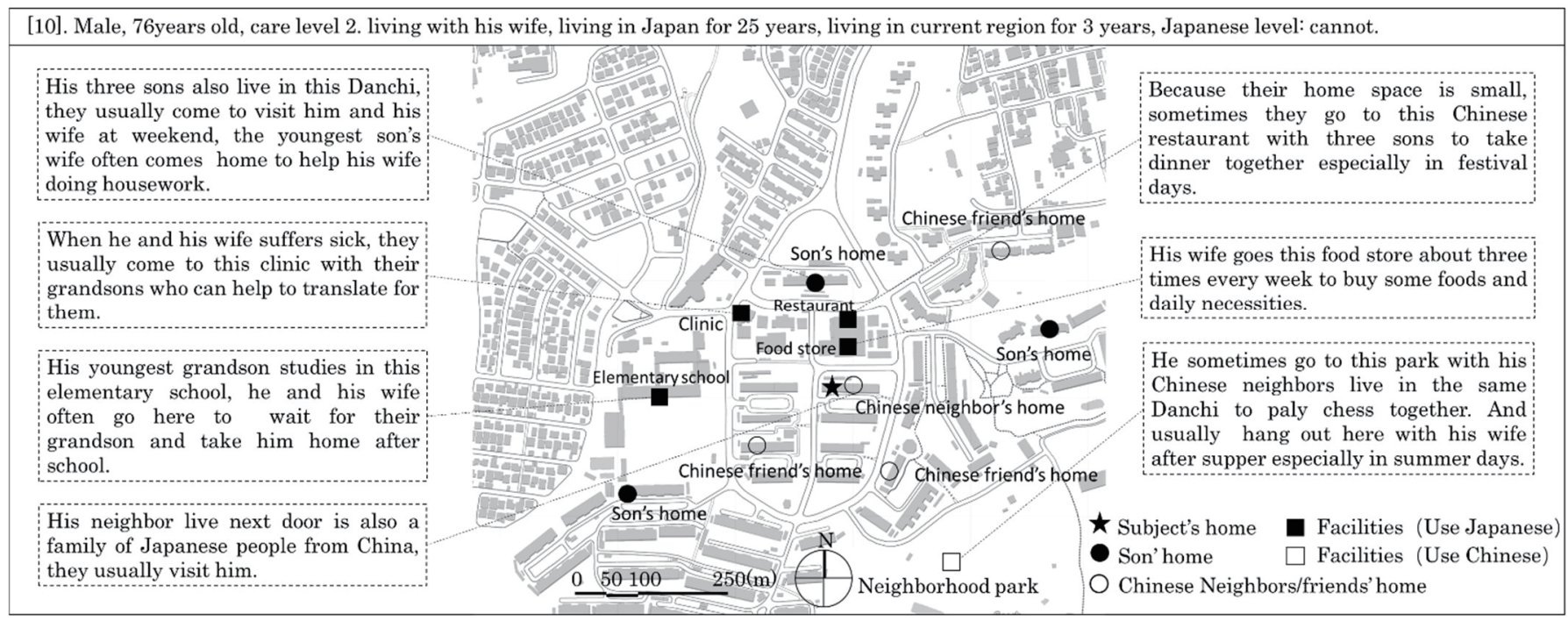

Fig.11 The case description of somewhat active type of community lifestyle in neighborhood

地域に、中国帰国者や在日中国人の数世帯が住んでおり、高齢者た ちがよく公園で集まって、中国語でお喋りしたり、遊んだりしてい る。彼女は週二回友達や末子の嫁と一緒に家の近くのスーパーへ買 い物に行っている。また、家の近くには中国語でコミュニケーショ ンができる中華物産店があり、彼女は時々この中華物産店へ買い物 やお喋りに行っている。現在、毎週の火曜日と金曜日に家の近くの 外国人向けの日本語教室で日本語を勉強している。時々、日本語教 室が主催する旅行や中国伝統芸術公演などの活動に参加している。

Fig.11 はややアクティブタイプの一例である。[10]は 76 歳の中 国帰国者二世の男性であり、妻と同居している。日本語能力は 「cannot」である。彼は 25 年前の 51 歳で来日し、来日後の 15 年 間一世の母親と仙台に住んでいた。息子 3 人が大阪で働いているた め、母親が亡くなった後大阪に引っ越した。3 年前、息子が住んで いる団地に引っ越した。平日息子の家族はよく彼を訪衩ている。祝 日の時、家族は近くの中華料理店で一緒に食事し、祝日を慶祝する。 末子の妻はよく彼の家に訪問し、家事を助けてあげている。この団 地にはたくさんの中国帰国者が住んでいる、彼には数名の帰国者友
達ができて、時々皆が近くの公園で集まって、一緒に将棋をしてい る。また、彼の隣家も中国帰国者であり、隣人がよく彼の家に訪問 し、一緒に食事したり、喋ったりしている。この団地の近くにはス 一パーがなく、小さい食品商店があって、彼と妻は週二〜三回ここ で買い物している。

\section{3）近隣環境に関する重要視するポイント}

対象者の全員は現在の近隣環境に満足している。対象者が近隣環 境において重要視するポイントに関するアンケート結果を Fig.12 に示す。「隣人との関係」の回答が最も多く、次いで、「買い物の利 便性」「家族が近くに住むこと」「公園の有無」「中国語が対応できる デイサービス」の順である。日本の安全性、清潔性、交通の利便性 が高いため、これらの項目を選択する対象者は少ない。近隣環境で は隣人との関係を最も重要視しているが、実際には隣人との関係を 持っていないことが明らかになった。

\section{6 住宅環境・社会環境・近隣環境の関係性}

住宅でのライフスタイル・近隣でのコミュニティライフスタイル・ 社会的つながりの程度の関係性を Fig.13 に示す。住宅でのライフス 


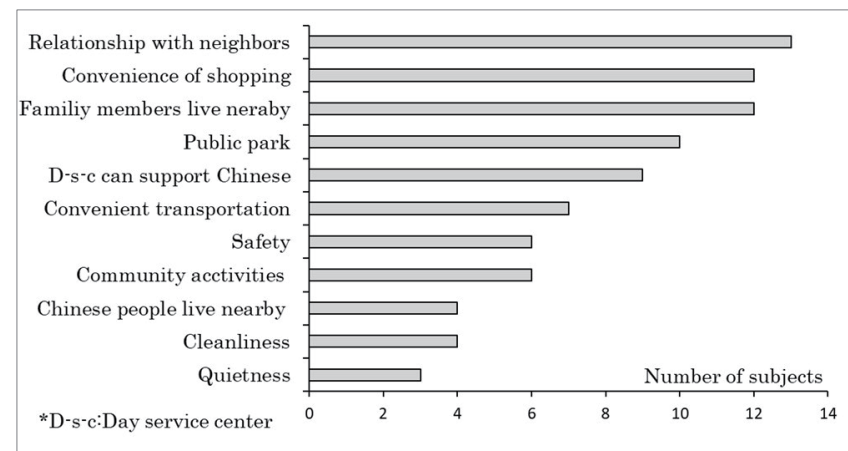

Fig.12 Important points regarding the neighborhood environment of 18 elderly JPC

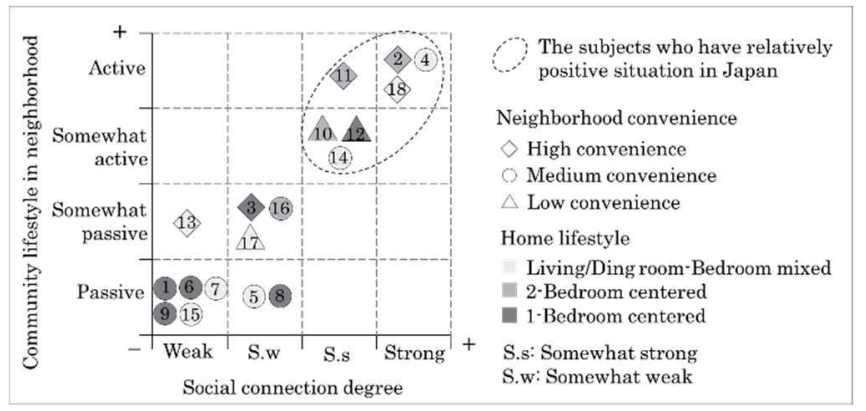

Fig.13 The combination of home lifestyle, community lifestyle and social connection degree of 18 elderly JPC

タイルは社会環境や近隣環境との関連性は低いが、社会環境と近隣 環境の関連性は高い。1 ベッドルーム中心の在宅ライフスタイルの 6 人のうち 3 人は、パッシブなコミュニティライフスタイルと弱い 社会的つながりの程度であった。2ベッドルーム中心やベッドルー ムとリビング・ダイニングルーム混在の在宅ライフスタイルの対象 者は、コミュニティライフスタイルと社会的つながりの程度がさま ざまである。また、近隣での生活利便性と近隣でのコミュニティラ イフスタイルの関係性について、アクティブタイプの 4 人の対象者 の中、3 人の対象者の近隣での生活利便性が高い、パッシブタイプ
の寸べての 7 人の対象者の近隣での生活利便性が中等度である。や やアクティブタイプとややパッシブタイプの対象者について、近隣 での生活利便性はさまざまである。また、近隣での生活利便性と社 会的つながりの関連性は低いと考えられる。

[2］４4］［18］のように近隣環境に中国語でコミュニケーション を取ることができる家族や隣人・友人がいることがアクティブな外 出となり、強い社会的つながりを持っている結果になったと考えら れる。一方で［1］［6］［7］［9＜wide>[15］のように近隣環境に家族や隣 人・友人がいない場合、外出に結び付かず、社会的つながりは中国 語で話すへルパーや中国帰国者向けのデイサービスの介護に関する 社会的つながりにとどまっている。また要介護度に注目すると、要 介護度 4 以上の［1］［6］は実質 1 人で外出することが困難である のでパッシブなコミュニティライフスタイルであり、中国語でコミ ユニケーションが取れる訪問ヘルパーあるいは同居する家族だけの 社交であり、弱い社交程度である。弱い社交程度かつパッシブなコ ミュニティライフスタイルである他の 3 人について、[7] は一人で 暮らし、時々訪れる家族と一緒に外で散歩や買い物している。［9］ は一人で暮らし、時々訪れる家族と一緒に外で散歩や近隣のデイサ ービスへ入浴に行っている。[15]は56歳の脳梗塞の息子と同居し、 平日全く外出していない。彼らの社交程度は家族と中国語でコミュ ニケーションが取れる訪問ヘルパーまたはデイサービスでの入浴す る介護員である。

また、対象者の全体的な現状については、[2]、[4]、[18]が最も良 く、[10]、[11]、[12]、[14]は 2 番目に良い。それ以外は比較的ネガ ティブな状況にあり、高齢中国帰国者のほとんどが日本でポジティ ブな生活現状を送っていないことを示している。

\section{7 中国から日本への移行による環境変化}

18 人の対象者へのアンケートとインタビューによって、日本に来 る前の中国での住環境と現在の日本の住環境を比較し、移行による 環境の変化に関する本人の評価を Table8 に示す。

住宅環境の項目で、住宅タイプ、平面レイアウト、住宅設備、プ ライベートスペースは全体的にポジティブな変化を示している。近 隣環境に関しては、ほぼすべての項目がポジティブな変化を示して いる。住宅環境と近隣環境のポジティブに評価をした理由は、中国

Table8 The environment changes caused by relocations from China to Japan's current home

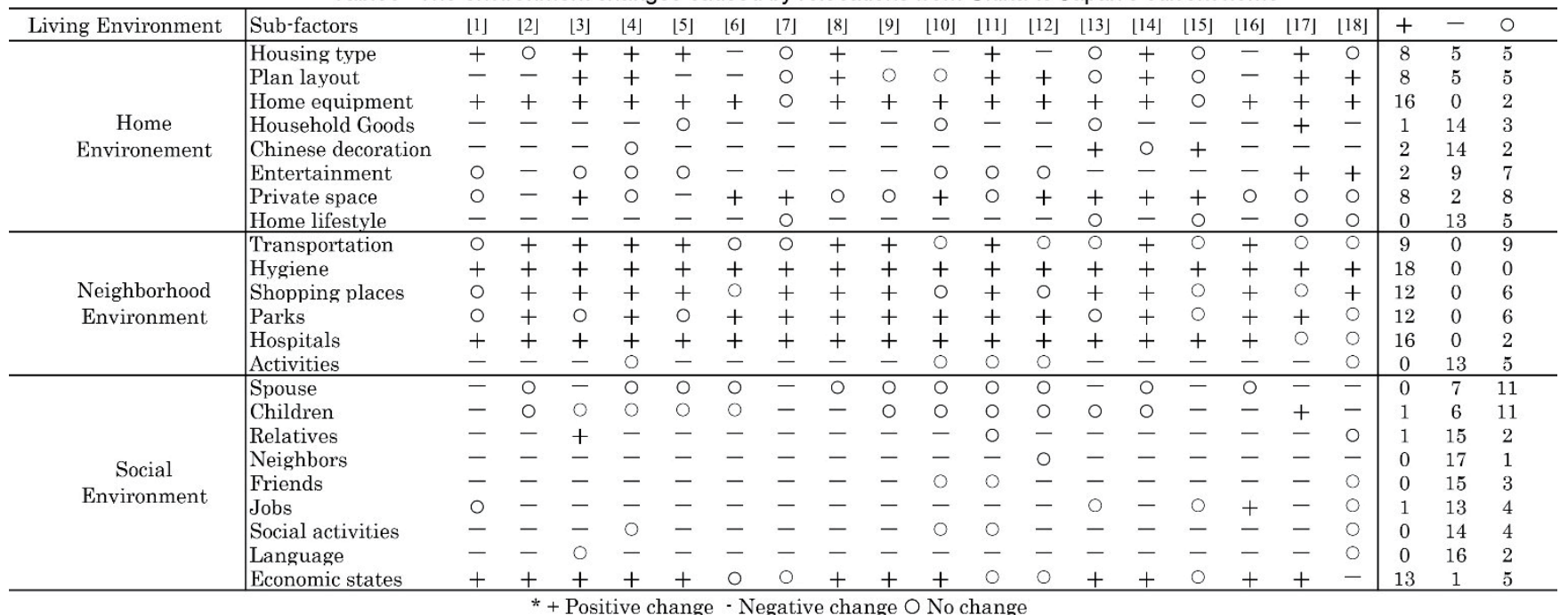


と日本の経済発展レベルが大きく異な点である。来日前までの中国 での生活水準や経済は日本より良くなく、特に半分以上の対象者が 中国の農村出身であり、都市部に比べてさらにそれらが良くなかっ た。来日後、政府からのサポートもあり生活水準や経済状況が大き く改善した。しかし、家族や経済状況を除き社会環境に関してほと んどの対象者がネガティブな評価をしている。日本語が不得手なこ とと、引っ越しを繰り返したことが影響していると考えられる注 10)。

\section{8. まとめ}

18 名の高齢中国帰国者を対象に環境移行による変化と現在の住 環境を明らかにした。下記に結果をまとめる。

（1）対象者全員は 1980 年代以降来日し、来日後、平均引っ越し 回数は 2 回であった。彼らが引っ越しする主な理由は公営住宅の 当選、子供たちとの別居、そして子供たちのキャリアの昇進である。

(2) 多くの対象者は、日本に来る前は経済状態が悪い農民であり、 また教育水準が低かった。来日後、半数が日本で仕事をしておらず、 工場でアルバイトをしていた。また日本語が話せない人が多かった。

（3）住宅環境について 12 人の対象者はバリアフリーがない市営 や府営住宅などの公営住宅に住んでいる。また、住宅環境に対する 不満足点や生活上の不便な点は、「バリアフリーがない」が最も多く、 バリアフリーの改修に関する情報を把握していなかった。

(4) 対象者の多くは日本人の友人がなく、中国人の友人も少ない。 また社会活動に参加していなかった。社会的つながりの程度がやや 弱い $(5$ 人)、弱い $(6$ 人 $)$ の人の多くは、家族・親戚や、中国語を 話すことができるへルパー・デイサービスに限定されていた。

（5）近隣環境について、外出の頻度と近隣の行動から、要介護度 も影響するが、「アクティブ」「ややアクティブ」タイプは、家族や 隣人や友人との交流で外出している割合が高かったが、「パッシブ」 「ややパッシブ」はそれらが見られなかった。またアンケートによ る主な近隣環境に関する重要視するポイントは「隣人との関係」を 挙げる人が最も多かった。

（6）中国から日本への移行による環境変化について、近隣環境が ポジティブな変化を示し、社会環境がネガティブな変化を示し、一 部の対象者は住宅環境がネガティブな変化を示している。

以上から、18 人の対象者のうち、7人は日本で比較的ポジティブ な状況にいるが、高齢中国帰国者のなかには中国語環境の中で生活 しており、日本で非常に孤立的に生活し、日本社会にうまく適応で きていないことが分かった。

最後に、高齢中国帰国者のエイジング・イン・プレイスの目標を 達成するために、住環境の改善について以下の視点から考察する。 (1)住宅環境について、中国帰国者は見守りや介護が必要になった後 在宅生活を継続するために、バリアフリーやキッチン換気などの住 宅改修のサポートと中国が話せる在宅生活支援業者や訪問介護員が 必要である。(2)近隣環境について、歩行能力が低下した高齢者、自 宅の近隣での生活利便性が低い高齢者、特に日本語が話せない高齢 者にとって、買物、医療、交通などの近隣での生活支援が必要であ る。(3)社会環境について、高齢中国帰国者が家族や友達以外の豊か な社会的つながりを築くために、地域や社会団体は彼らが参加でき る活動を行う必要がある。特に介護が必要になるときに中国帰国者 向けのデイサービスセンターは、中国帰国者のコミュニケーション
の場も提供し、重要な役割を果たしていると考えられる。

謝辞 本研究は、一般社団法人住総研による助成を受けて行った。

注

注 1) 昭和 20 年 8 月 9 日時の年齢が 13 歳未満であった中国残留日本人は残 留孤児と呼ばれる。昭和 20 年 8 月 9 日時の年齢が満 13 歳以上であった中 国残留日本人は男女を含めて「残留婦人等」と呼ばれる。ほとんどが女性 であるため「残留婦人」と称される場合もある20)。

注 2) 永住帰国旅費 (国費) の支給対象者は残留邦人本人とその配偶者、20 歳 未満の実子又は身体等に障害のある実子。「中国残留邦人等の円滑な帰国 の促進及び永住帰国後の自立の支援に関する法律(平成 6$) 」$ 第 6 条、支援法 施行規則第 10 条。

注 3）帰国者数に関する正確な統計は行われていないが、帰国者 1 人当たりの 日本在住の家族数は、国費同伴、呼び寄せ家族を含めて孤児が 9.4 人、婦 人等が 11.8 人となっている ${ }^{21)}$

注 4) 米国疾病予防管理センターは、エイジング・イン・プレイス (Aging in Place）を高齢者が年齢、収入、能力レベルにかかわらず、住み慣れた地域 で安全かつ自立して快適に暮らすことと定義している 22 。

注 5）新支援法は帰国者二世には一切適用されない。二世は普通の日本人と同 じ、特別な支援政策がない。ただし、高龄になった二世の生活は経済的に 困窮し、多くが生活保護に頼らざるをえない状況である。近年、日本各地 の「中国帰国者二世連絡会」は、新支援法を改正し中国帰国者二世に対し て支援給付金と老齢基礎年金を支給すること、自立支援通訳の派遣で医療・ 行政サービスや日本語学習が容易に受けられるようにすることなどを求め ている。

注 6）中国では、1955 年から、計画経済と配給制度を運営するため、全国の 人口を農業人口と非農業人口に区別する戸籍制度が設定された。1990 年代 前、農民は自由に都市に移行できず、収入又は福祉の面で都市の居民が大 きく異なっていた。ほとんどの農民は低所得者であった。

注 7）趙萍らは、中国帰国者が日本に来た後、まだベッドで寝ることと椅子座 などの中国の起居様式を維持していると指摘している ${ }^{23)}$ 。

注 8）厚生労働省の統計により、令和 2 年 9 月 30 日まで、日本全国には、中 国語対応が可能な介護事業所数が 374 か所女る。大阪府は 34 か所がある。 多くの介護事業所は中国帰国者又は在日中国人向けの事業所である ${ }^{24) 。}$

注 9）国土交通省により、日本の都市住区基幹公園の種類を街区公園、近隣公 園、地区公園と分類する ${ }^{25)}$ 。

注 10) Shigehiro Oishi は、人間の幸福感が頻繫な引っ越しで低下する傾向が あると指摘している。頻繁な引っ越しは人間の社会関係に大きく影響を与 え、それ故、幸福感が社会関係に大きい影響を受けていると考えられる ${ }^{26)}$

\section{参考文献}

1) Fujinuma, T.: Chronology: History and development of Support Policy of Japanese people from China, Bulletin of the support and communication center for Japanese people from China, No6, 1998.05 (In Japanese) 藤沼敏子: 年表: 中国帰国者問題の歴史と援護政策の展開, 中国帰国者定着 促進センター紀要 6 号, 1998.5

2) Ministry of health, labor and welfare: Summary of survey results of Japanese orphans in China, (As of August 31, 1st year of Reiwa), https://www.mhlw.go.jp/stf/seisakunitsuite/bunya/bunya/engo/seido02/k ojitoukei.html (accessed 2020.9.10)(In Japanese) 厚生労働省：中国残留邦人の状況（令和元年 8 月 31 日現在）, https://www.mhlw.go.jp/stf/seisakunitsuite/bunya/bunya/engo/seido02/ kojitoukei.html (参照 2020.9.10)

3) Ministry of health, labor and welfare: Summary of survey results of Japanese orphans in China, 2015 (In Japanese) 厚生労働省 : 中国残留邦人等実態調査結果の概要, 2015

4) Public interest incorporated foundation, Assistance found of Japanese orphans in China, The support and communication center for Japanese people from China: The result summary of questionnaire survey for second and third generation of Japanese people from China, 2020.5 (In Japanese)

公益財団法人，中国残留孤児援護基金，中国帰国者支援・交流センター： 中国帰国者二三世質問紙調査の結果概要，2020.5

5) Tadashi Toyama: Identity and milieu: a study of relocation focusing on 
reciprocal changes in elderly people and their environment, Department for Building Function Analysis, the Royal Institute of Technology, pp. $13-15,1988.1$

6) Charles Walker, PhD, RN, C.: Relocation Stress Syndrome in Older Adults Transitioning from Home to a Long-Term Care Facility, Journal of Psychosocial Nursing and Mental Health Services, 45(1), pp.38-45, 2007

7) Takei, T., Araki, H., and Kametani, C.: Study on Living Environment of Foreign Elderly People from the Living Environment in Special Nursing Home for Elderly Koreans Living in Japan. Architectural Institute of Japan Kinki Branch Research Report, Planning, pp.181-184, 2001(In Japanese)

武井民典, 荒木兵一郎, 亀谷義浩 : 外国人高齢者の居住環境に関する研究 : 在日韓国・朝鮮人高齢者の特別養護老人ホームにおける居住環境に関する 研究, 日本建築学会近畿支部研究報告集, 計画系, pp, 181-184, 2001

8) Kakehi, M, Komatsu, H.: Spatial Problems in Forming a Place for Immigrants in Japan - A Case Study on a Group of Small Shops Established by Immigrants and Removed in a Housing Complex, Journal of Architecture and Planning (Transactions of AIJ), Vol.79, No.704, pp.2165-2172, 2014.10 (In Japanese)

筧政憲，小松尚：外国人居住者の居場所形成における空間的課題一 $\mathrm{A}$ 団地 において自主建設されたものの, 撒去された店舗群の分析, 日本建築学会 計画系論文集，Vol.79, No.704, pp.2165-2172, 2014.10

9) Kitahara, R. and Otsuki, T.: A Study on Living Environment of Bangladesh Nationality Foreign Residents in Kita-ku, Tokyo - influence on the Concentrated Area at a Migrant Workers Receiving Country from Chain Migration Based on International Manpower Movement, Journal of Architecture and Planning (Transactions of AIJ), Vol.79, No.698, pp.873-882, 2014.4 (In Japanese)

北原玲子, 大月敏雄：東京都北区のバングラデシュ国籍在留外国人の居住 環境に関する研究-国際労働力移動による連鎖移民が受け入れ国の集住地 に及ぼす影響, 日本建築学会計画系論文集, 第 79 巻, 第 698 号, pp.873$882,2014.4$

10) Kakino, Y. and Hatsumi, M.: A Study on the Lifestyle of Foreign People in a Suburban Public Housing Estate - A Case study in Icho Housing Estate in Kanagawa Prefecture. Journal of Architecture and Planning (Transactions of AIJ), Vol.75, No.652, pp.1355-1363, 2010.6 (In Japanese)

垣野義典, 初見学: 外国籍住民の郊外団地居住の実態 - 神奈川県いちょう 団地を事例として, 日本建築学会計画系論文集, 第 75 巻, 第 652 号, pp. 1355-1363, 2010.6

11) Aizezi, M., Umemoto, M., Toyokawa, S. and Kobayashi, H.: A Study on the Dwelling of Taking of Footwear through Changing of Seating Style of Uyghurs in Japan - A Case Study on the Change of Dwelling Style in Environment Transition to Different Dwelling Culture. Journal of Architecture and Planning (Transactions of AIJ), Vol.85, No.767, pp.1121, 2020. 1 (In Japanese)

マヒラ エゼズ，梅本 舞子，豊川 斎赫，小林 秀樹 : 在日ウイグル族の起 居様式の変化を通した床上文化の考察 - 異なる住文化への環境移行に伴う 住まい方の変容に関する研究, 日本建築学会計画系論文集, 第 85 巻, 第 767 号, pp.11-21, 2020.1

12) Yamaguchi, K. and Miura, K.: Environmental Adaption in Residential Facility for the Elderly - Through the Effort in Architecture Planning Aims for the Realization of Adaptable Environment for the Elderly. Japan Society of Physiological Anthropology, Vol.8, No.4, pp.29-36, 2003. 11 (In Japanese)

山口健太郎, 三浦研 : 高齢者居住施設と環境適応 : 高齢者が適応しや寸い施 設計画の取り組みを通して, 日本生理人類学会誌, 第 8 巻, 第 4 号, pp. 29-36, 2003.11

13) Yan, S., Ishii, S. and Nagasawa,Y: A Study on the Group Living for the elderly Suffered from Dementia from the Point of Environment Transfer and Terminal Care. Journal of Architecture, Planning and Environmental Engineering (Transactions of AIJ), No.557, pp.165-171, 2002.7 (In Japanese)

厳爽，石井敏，長沢泰：生活環境の移行とターミナルケアの視点から見た 痴呆性高齢者のあり方に関する研究, 日本建築学会計画系論文集, 第 557
号, pp.165-171, 2002.7

14) Kumahara, H. and Nishida, J.: Physical Fitness and Quality of Life for Japanese People From China-Current Status of Users of the Support and Communication Centers For Japanese People From China, Journal of health and welfare statistics, Vol.61, No.5, pp.31-138, 2014.5 (In Japanese)

熊原秀晃, 西田順一: 中国帰国者における体力および生活の質一帰国者支援・ 交流センター通所者の現状，厚生の指標，第 61 巻，第 5 号, pp.31-138, 2014.5

15) Wang, R. and Sibuya, T.: Current Status and Issues of Care Support for the Elderly Foreigners Living in Japan from the viewpoint of care problems for Japanese People from China, Chukyo University Academic Information, Social Science Research, 38(2), pp.2-18, 2018.3. (In Japanese)

王榮，渋谷努：中国帰国者の介護問題から見た在住外国人高齢者への介護 支援の現状と課題, 中京大学学術情報, 社会科学研究, 38(2), pp.2-18 2018.3

16) Yamada, M., Yamaguchi, k. and Takada, M.: Relationship Between Living Space and the Quantity and Type of Household Goods in Serviced Housing Units for the Elderly, Journal of Architecture and Planning (Transactions of AIJ), Vol.83 No751, pp.1623-1633, 2018.9 (In Japanese) 山田雅之, 山口健太郎, 高田光雄 : 高齢者向け住宅の住戸空間における物 品の種類および量と空間の関係性，日本建築学会計画系論文集，第 83 巻， 第 751 号, pp.1623-1633，2018.9

17) Bekhet, A. K., Zauszniewski, J. A., and Nakhla, W. E.: Reasons for relocation to retirement communities: A qualitative study. Western Journal of Nursing Research, 31, pp.462 - 479, 2009

18) Berth, D. Danermark and Mats, E. Ekstrom.: Effects of residential relocation on mortality and morbidity among elderly people. European Journal of Public Health, Volume 6, Issue 3, pp.212-217, 1996.9

19) Mari Smith.: The New Relationship Marketing: How to Build a Large, Loyal, Profitable Network Using the Social Web. Hardcover - Illustrated, pp.75-79, 2011.10

20) Ministry of health, labor and welfare: White paper on Japanese orphans in China, 1987(In Japanese)

厚生労働省：中国残留孤児白書, 1987

21) Ministry of health, labor and welfare: Survey results of the living conditions of Japanese people from China, 2005.3 (In Japanese) 厚生労働省：中国帰国者生活実態調査の結果, 2005.3

22) U.S. Centers for Disease Control and Prevention: Public health terms for planners \& planning terms for public health professionals. https://www.cdc.gov/healthyplaces/terminology.htm (Accessed 2020.10. 02)

23) Zhao. P and Machida. R: A Study on the Dwelling Life of the Returnees from China A Case of People Living in the Stricken Area of the Great Hanshin-Awaji Earthquake: In Contrast with People Living in Kyoto, Journal of home economics of Japan, Vol,49, No,7 pp.811-820, 1998 (In Japanese)

趙萍，町田玲子：中国帰国者の住生活に関寸る研究一阪神・淡路大震災の 被災地の居住者の場合: 京都在住者と比較して, 日本家政学会誌, 第 49 巻, 第 7 号, pp. 811-820, 1998

24) Ministry of health, labor and welfare: List of care establishments that can support Chinese language service, 2020.9.30 (In Japanese) 厚生労働省：中国語の対応が可能な介護事業所一覧, 2020.9.30

25) Ministry of Land, Infrastructure, Transport and Tourism, City Bureau: Types of city parks,

https://www.mlit.go.jp/crd/park/shisaku/p_toshi/syurui/ (accessed 2020.10.15) (In Japanese)

国土交通省, 都市局 : 都市公園の種類

https://www.mlit.go.jp/crd/park/shisaku/p_toshi/syurui/ (参照 2020.10. 15)

26) Shigehiro Oishi.: The Psychology of Residential Mobility: Implications for the Self, Social Relationships, and Well-Being. Perspectives on Psychological Science, pp. 5-21, 2010.5 


\title{
RESEARCH ON ENVIRONMENTAL TRANSITION AND LIVING ENVIRONMENT OF ELDERLY JAPANESE PEOPLE FROM CHINA
}

Through a survey of first and second generation of Japanese orphans in China and their spouses

\author{
Wenlei DING ${ }^{* 1}$, Shigeki MATSUBARA ${ }^{* 2}$, Motoki SHIMODA ${ }^{* 3}$ \\ and Michihiro KITA *4
}

\author{
${ }^{* 1}$ Grad. Student, Division of Global Architecture, School of Engineering, Osaka Univ. \\ *2 Assoc. Prof., Division of Global Architecture, School of Engineering, Osaka Univ., Dr.Eng. \\ *3 Junior Assoc. Prof., Faculty of Architecture and Arts, Otemae Univ., Dr.Art. \\ * ${ }^{4}$ Prof., Division of Global Architecture, School of Engineering, Osaka Univ., Dr.Eng.
}

This paper studied environmental transition and living environment of the elderly Japanese people from China. It is purposed to understand their process of relocations from China to the current home in Japan and the environment changes caused by relocations. Furthermore, this study is to understand their present living environment and finally help them to adjust Japan society well, so that they can continue to live in the region to reach the goal of "aging in place."

All the 18 research subjects are living in Osaka prefecture. Field surveys have been taken in their homes and neighborhood, meanwhile, questionnaire and interview have been performed with them and their family members.

This survey finds that all of them came to Japan after 1980s, and most of them were farmers in China at very low economic state before coming to Japan. Due to the low education level and the old age, many of them cannot speak Japanese and half of them had no jobs in Japan, some had part time jobs in factories. After coming to Japan, most of them moved several times.

As for living environment, most of them live in public houses, like municipal or prefectural houses, without barrierfree facilities. In addition, the most dissatisfied points and inconveniences about the housing environment in daily life were "no barrier-free", and they do not know the information of the government's support policy for barrier-free reform. Meanwhile, their social relationships are limited to family members, relatives and visit care helper who can speak Chinese. Based on the frequency of going out and the behavior variety in neighborhood, their community lifestyle can be defined into 4 types as: Active (4persons), Somewhat active (3persons), Somewhat passive (4persons), and Passive (7persons). And as for the environment changes caused by the relocation from China to Japan, their neighborhood environment shows an overall positive change, the social environment shows totally negative changes.

From the above, it finds that most of the elderly Japanese people from China live very isolate life in Japan and do not adapt to Japanese society well. Some of the 18 subjects are in a relatively positive situation in Japan, but they still live in Chinese environment, have little connection to Japanese society, and do not integrate into Japanese society.

Due to their poor Japanese proficiency and frequent moving, they cannot make local friends and are less likely to participate in community activities. Before using Chinese visiting services and day service centers support Chinese language, their social connections were based on family members and a small number of Japanese people from China or Chinese friends living nearby. Some people even have no other connection except for family members and visiting helpers. In other words, most elderly Japanese people from China are less social and lead a very isolated life in Japan. Therefore, in the future, in order for the elderly Japanese people from China to establish rich social connections besides family members and friends, the communities and social groups should organize some activities that they can participate in. Particularly, the day service center for Japanese people from China may provide a place for communication with other Japanese people from China or Chinese people living in Japan, and plays an important role in reducing their isolation in Japan. 